\title{
Energy Consumption Analysis in Katsuwonus Pelamis sp. Freezing and Storaging Process
}

\author{
Khalif Ahadi ${ }^{1}$, Guntur Tri Setiadanu, ${ }^{1, *}$, Yohanes Gunawan ${ }^{1}$, Subhan Nafis ${ }^{1}$, Dedi Suntoro ${ }^{1}$ \\ ${ }^{1}$ Renewable Energy and Energy Conservation Technology (P3tek KEBTKE), Ministry of Energy and \\ Mineral Resources (KESDM), Bogor, 16340, Indonesia
}

\begin{abstract}
A fresh fish has a short limited fresh time without treatment. To maintain quality and prevent spoilage, several treatments are carried out especially using a cooling method. In the fish storage industry, most energy consumed by cooling equipment. With the rising of energy prices, the frozen fish industries are looking for possibilities to reduce production costs by saving energy. Energy-saving assessment can be seen from the specific energy consumption (SFC) which is a comparison of the amount energy needed to produce a product ( $\mathrm{kWh} /$ ton of product). This article will be discussed about data collection and analysis to get the value of SFC for process and storage in the fish freezing and storage services industry. The measurement result shows that the value of SFC for cold storage are 4.2 $\mathrm{kWh} / \mathrm{ton}$. The SFC used by the air blast freezer (ABF) with 5 tons capacity are $91 \mathrm{Wh} / \mathrm{kg}$. The consumption of electrical energy in ABF is strongly influenced by matched between the capacity specifications of $\mathrm{ABF}$ and the number of fish to be cooled. If the 5 tons $\mathrm{ABF}$ is only filled less than 2 tons of fish, the SFC will increase more than $50 \%$ up to $145 \mathrm{Wh} / \mathrm{kg}$.
\end{abstract}

\section{Introduction}

Based on data released by the Food and Agriculture Organization (FAO) in 2016, the average capture fisheries production from 2003-2012 compared to 2013-2014, Japan fell 12.5\% and South Korea fell $1 \%$. Meanwhile, in the same period, Indonesian fisheries production increased by $26.8 \%$ [1]. However, Indonesia has not been included in the top 10 fish exporting countries in the world [2]. This is partly due to the way of handling and processing fresh fish after catch has not met the criteria needed by export consumers.

Fresh fish contains up to $80 \%$ water and is highly perishable so it has a short limited fresh time. If fresh fish is not immediately used or processed into finished products, it will become waste [3] The fishery products are usually more quickly damaged when compared with the other muscular meat products. Freshly caught fish will changes in quality due to autolysis and bacterial activity. This rate of change determines shelf life. Proper storage conditions are very important to prevent spoilage of fishery products [4]. To maintain quality and prevent spoilage, several treatments were carried out including using high pressure processing, irradiation, microwave, ultrasound processing, vacuum packaging, also the use of enzymes

\footnotetext{
${ }^{*}$ Corresponding author: guntur.setiadanu@gmail.com
} 
[5]. In addition, there are other methods that are widely used and simple, such as drying, fuming, salting and cooling.

The food processing industry is a significant user of water, energy and packaging materials, and also produces large amounts of waste and emissions. In the UK, the greenhouse gas footprint in the food industry is responsible for around $13 \mathrm{MtCO}_{2} \mathrm{e}$ (million tons $\mathrm{CO}_{2}$ equivalent) and the main energy consumption of $42 \mathrm{TWh}$ [3]. Typically, in the food industry, around $68 \%$ of energy is used by direct heating systems, $16 \%$ is electrical energy used by electric motors, $8 \%$ is used by electric heaters, $6 \%$ by cooling equipment and the remaining $2 \%$ by air compressors [5]. But in the fish processing and storage industry, almost all of energy is consumed by cooling equipment.

Energy utilizations in fish processing plants are dominated by refrigeration and freezing facilities. About $80 \%$ of electricity consumed at the plant is provided for refrigeration compressors in freezing and storage facilities. Energy is also needed for cooling the production room [6]. The equipment includes air blast freezer (ABF) and cold storage (CS). At $\mathrm{ABF}$, high-speed air at temperatures around $-30^{\circ} \mathrm{C}$ is exhaled on top of the product. The velocity of air to freeze fish is between 2.5 and $7.5 \mathrm{~m} / \mathrm{s}$. High speed can result in faster freezing but also higher unit freezing costs and dehydration in the untreated fish [7].

In general, CS chiller consists of 3 main components as shown in Figure 1, namely: condensing unit (compressor and evaporator); air condenser; fan condensing unit (FCU) blower; and expansion valve. Components that consume electricity are compressors, aircooling blowers, FCU blowers. The compressor works intermittently based on pressure and temperature settings, the air cooler blower works intermittently following the compressor, and the FCU blower works continuously.

Cold storage volume has a significant impact on energy use. For chilled CS, 93\% of energy use is related to storage volume. For frozen CS, $56 \%$ of energy is related to storage volume, while for the combination of both CS, $67 \%$ of energy consumption is related to volume. Cold storage form factors and surface area, ways of use, and environmental conditions can influence energy consumption [8].

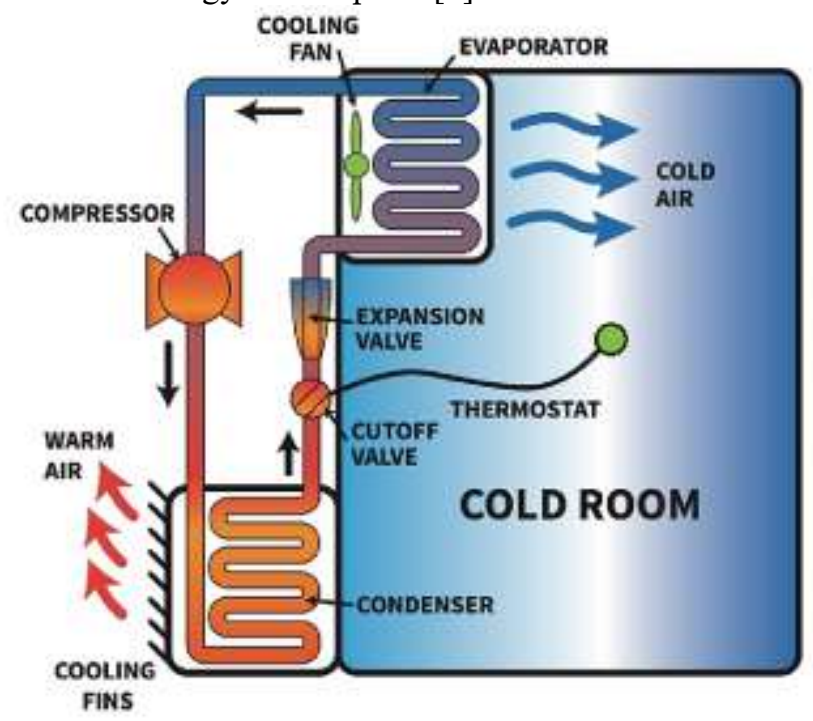

Fig. 1. Components and refrigeration piping systems in cold storage [9]

Based on research others research, Murtono, 2014 said that for CS with a capacity of up to 123.5 tons in normal operation has a cooling load of around 82,717.32 Btu/hr [10]. Meléndez-Pérez, 2011 said that the freezing thermal profile without opening the door shows 
typical freezing behavior with a total time about 242 minutes: 23 minutes for adjustment, 61 minutes to the zone of phase change and crystal growth, and 159 minutes to sub cooling [11].

With the rising of energy prices, producers are looking for opportunities to reduce costs without affecting quality. Investment in energy saving technology can make a significant contribution to the reduction of production costs [5]. Energy saving performance can be seen from the specific energy consumption or energy consumption intensity which is a comparison of the amount of energy needed to produce a product [12-13]. Specific energy consumption is used as a measure of energy savings. In Indonesia, the calculation of the value for specific energy consumption has not been done much, including for fish processing. This is different from other countries. Based on studies that have been carried out in Vietnam, specific energy consumption in processing fresh fish is around $400 \mathrm{kWh} /$ ton, or $1400 \mathrm{kWh} /$ ton fish fillets [6]. As a comparison, generally for the salmon processing industry in 2015 in Norway requires energy around $85.1 \mathrm{kWh} /$ ton to $105.7 \mathrm{kWh} /$ ton [14]. Globally, the average fish freezing process requires around $120 \mathrm{kWh} /$ ton of energy, and for storage process around 20 $\mathrm{kWh} /$ ton [15].

The purpose of this study was to determine the specific energy consumption (SFC) in fish processing, freezing and storage in one of the fish processing service industries in Sidoarjo East Java. Skipjack (katsuwonus pelamis sp.) is one of the most widely caught and produced fish in Indonesia. There is no literature that shows the value of SFC in the production process of freezing skipjack fish in Indonesia. So it is difficult to reduce energy consumption in the production process. By knowing the specific energy consumption, energy saving evaluation can be taken by the plant manager.

\section{Materials and Methods}

The data measurement is carried out at PT. Jala Lautan Mulia (JLM), one of the refrigerated fish processing, freezing and storage industry. Primary data collection is done by direct observation and measurement without disrupting the production process. In this case, the fish produced are frozen skipjack (katsuwonus pelamis), weighing around 300-600 gr.

Measurements were made to obtain electrical parameters as well as temperature parameters as the objective value of the cooling work. The Hioki 3197 power quality analyser is mounted on the electrical load panel with data sampling every 30 minutes. There are 2 load panels, namely panel 1 which supplies cold storage and air conditioner for the production room, and panel 2 which supplies ABF. Measurements were made for 1 week. Cold storage and $\mathrm{ABF}$ room temperature measurements were performed using a thermocouple connected to the Graphtec GL7000 data logger. Whereas secondary data is obtained from the production's log sheets. The analysis was carried out to get the value of specific energy consumption in the fish freezing process.

\section{Result and discussion}

The process of fish freezing and storage process at PT. JLM complies with Indonesian national standard, SNI 4110-2014 which regulates frozen fish process. This is shown in Figure 2 [16].

At PT. JLM, the fish received have been weeded. This raw material then washed again, and weighed. The next process is packing to maintain the water content of the fish. Some consumers choose vacuum packaging. After that, the fish is placed on a rack to be put into $\mathrm{ABF}$. The next process, the fish are stored in CS. 


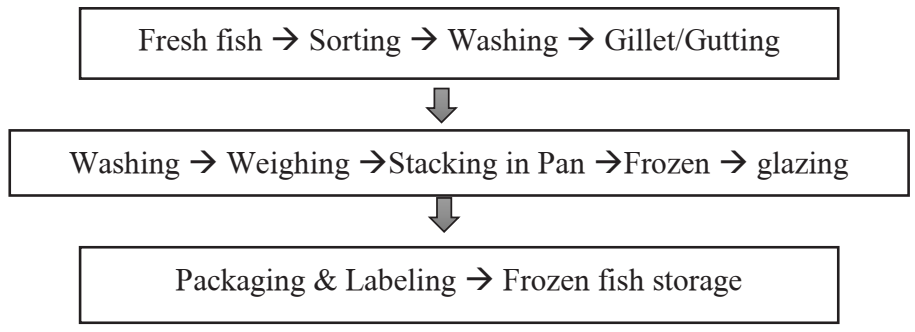

Fig.2. Flow process of frozen fish production [16]

Cold storage room is supported by two CS machines which are used to maintain two interconnected cooling rooms. This means that the 2 machines work simultaneously to maintain room temperature. At the time of measurement, CS is used to store about 150 to 170 tons of product, varying according to product entry and exit. For example, full one day measurement chart is taken, as shown in Figure 3. Based on the temperature graph, the same operating pattern of CS every day can be divided into two zones. Zone 1 is a 'production zone' between 08:00 17:00. This is indicated by the temperature fluctuations in the cold room due to opening and closing the door when mobilizing the product. Zone 2 is a 'storage zone' between 17:00 08:00, which shows the temperature becomes more stable, corresponding with the engine's work cycle.

The compressor works by regulating the refrigerant pressure and temperature, which is a representation of the temperature inside CS. The compressor works in temperature range of $-15^{\circ} \mathrm{C}$ to $-17.8^{\circ} \mathrm{C}$, meaning that if the $\mathrm{CS}$ room temperature is above $-15^{\circ} \mathrm{C}$ then the compressor and blower air cooler will work until it reaches a temperature of $-17.8^{\circ} \mathrm{C}$ then return to stand-by conditions. The FCU blowers work continuously to deliver cold from the refrigerant to CS room.

\subsection{Cooling Storage (CS) Energy Consumption}

\subsubsection{Electricity Consumption of CS during Production Zone}

The pattern of cold storage operation showed in Figure 3 and calculation of the amount of energy used during the production zone can be seen in Table 1. During full load, compressors and blowers work continuously, this is due to the opening and closing of doors when mobilizing products and increases the temperature room to exceed $-15^{\circ} \mathrm{C}$. During the production zone, the compressor starts up 3 times, once at the start of production and 2 times during recess. The startup process is a momentary process (in micro seconds) that requires high power. High instantaneous power consumption at the start-up process causes the need for electric power subscriptions are higher than the power requirements needed.

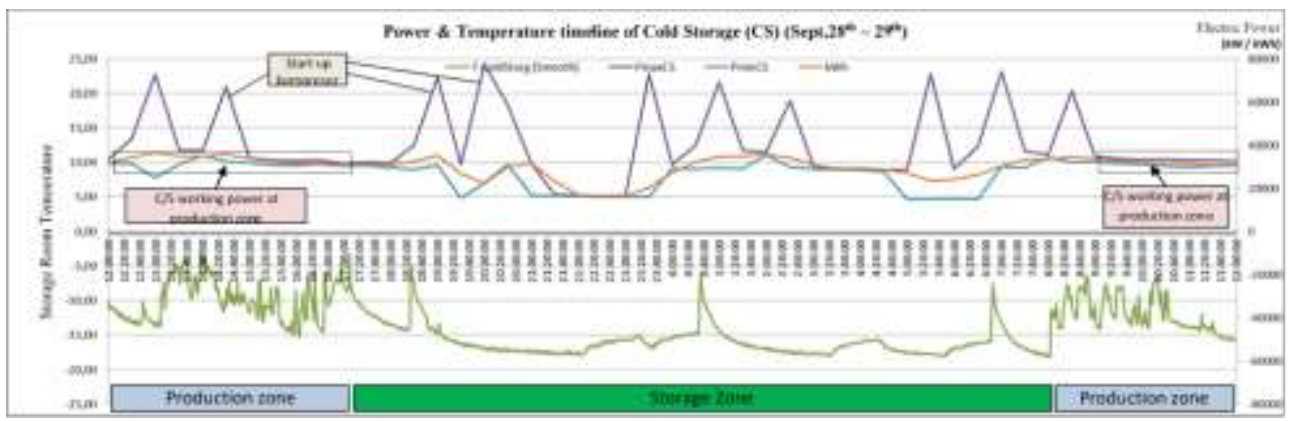

Fig. 3. The pattern of cold storage (CS) operations at PT. JLM 
Table 1. Work cycle of CS machines in the production zone (08:00 - 17:00)

\begin{tabular}{|c|c|c|c|}
\hline Process & Duration & $\begin{array}{l}\text { Power (W) } \\
(\text { max-min) }\end{array}$ & $\begin{array}{l}\text { Avg. Energy } \\
\text { (Wh) }\end{array}$ \\
\hline Start up & $<1 \mathrm{sec}$ & $72800 \sim 67000$ & \\
\hline $\begin{array}{l}\text { Full running (compressor + } \\
\text { blower are on) }\end{array}$ & $\begin{array}{l}\text { 08:00 12:00 } \\
\text { 14:00 17:00 }\end{array}$ & $33500 \sim 31700$ & 32600 \\
\hline Break time ( 2 x start up) & 12:00 14:00 & $36700 \sim 31100$ & 33900 \\
\hline \multicolumn{2}{|c|}{$\begin{array}{l}\text { Total energy cold storage at production zone } \\
\text { (Full run + breaktime) }\end{array}$} & \multicolumn{2}{|c|}{$\begin{array}{l}(32600 \times 7)+(33900 \times 2) \\
=228200+67800 \\
=296000 \mathrm{Wh}^{*}\end{array}$} \\
\hline
\end{tabular}

*) The average $\mathrm{kWh}$ method here is only a rough depiction of the $\mathrm{kWh}$ calculation that occurred, while the real $\mathrm{kWh}$ that occurred will be presented at Table 3 below, as confirmation of this calculation.

\subsubsection{Electricity consumption of CS during the storage zone}

Storage zone is CS that work after production time (Table 2) which is the machine cycle to maintain the temperature in the CS chamber. In this condition, the compressor and air cooled blower only work when the temperature rises to higher than $-15^{\circ} \mathrm{C}$ and only works to reduce the temperature in a range that is less than about $3^{\circ} \mathrm{C}$ to reach the targeted temperature of $17.8^{\circ} \mathrm{C}$. This makes the workload of the compressor and blower air cooler not too large, so the electricity consumed is not as high as during the production zone.

Table 2. Work cycle of CS machines outside the production zone (17:00 - 08:00)

\begin{tabular}{|l|c|c|}
\hline \multicolumn{1}{|c|}{ Process } & Duration & \multicolumn{1}{c|}{$\begin{array}{c}\text { Power (W) } \\
\text { (max-min) }\end{array}$} \\
\hline $\begin{array}{l}\text { Temperatur cooling after production } \\
\text { zone }\end{array}$ & $17: 00 \sim 22: 00$ & $35500 \sim 11600$ \\
\hline Keeping targeted temperatur & $22: 00 \sim 08: 00$ & $33100 \sim 4600$ \\
\hline $\begin{array}{l}\text { Start up (occur eleven times, } \\
\text { compressor \& blower) }\end{array}$ & $<1 \mathrm{~s}$ & $76700 \sim 52000$ \\
\hline
\end{tabular}

Table 3. Actual electrical energy measurement results on panel 1 for cold storage

\begin{tabular}{|c|c|c|c|c|c|}
\hline \multirow[t]{2}{*}{ Date } & \multicolumn{3}{|c|}{$\begin{array}{l}\text { Storage Zone } \\
(17: 00 \sim 08: 00)\end{array}$} & \multirow{2}{*}{$\begin{array}{c}\begin{array}{c}\text { Production Zone } \\
(08: 00 ~ 17: 00)\end{array} \\
\text { Energi (Wh) }\end{array}$} & \multirow[t]{2}{*}{ Notes } \\
\hline & 17:00 & 8:00 & Energi (Wh) & & \\
\hline Sept, 27 28 $8^{\text {th }}$ & 210500 & 615500 & 405000 & & \\
\hline Sept, 28 29th & 913900 & 1338900 & 425000 & 298400 & \\
\hline Sept, 29 30 $0^{\text {th }}$ & 1633200 & 2049800 & 416600 & 294300 & \\
\hline Sept, $30^{\text {th }} \sim$ Oct, $1^{\text {st }}$ & 2344300 & 2700700 & 356400 & 294500 & \\
\hline Oct, $1 \sim 2^{\text {nd }}$ & 2969800 & 3230700 & 260900 & 269100 & holiday \\
\hline Oct, $2 \sim 3^{\text {rd }}$ & 3531200 & 3825100 & 293900 & 300500 & \\
\hline Oct, $3 \sim 4^{\text {th }}$ & 4118200 & 4476900 & 358700 & 293100 & \\
\hline Oct, $4 \sim 5^{\text {th }}$ & 4777900 & 5109000 & 331100 & 301000 & \\
\hline
\end{tabular}

\subsubsection{Electricity consumption per day of cold storage}

Based on the measurements that have been made, it is obtained the value of electrical energy consumption $(\mathrm{kWh})$ recorded every hour. With reference to the predetermined cycle, the amount of energy consumption in the production zone (between 08: $00 \sim 17: 00$ ) and the storage zone (between 17: $00 \sim 08: 00$ ) is shown in Table 3. The measurement results show 
the highest value of electrical energy consumption when production is $301 \mathrm{kWh}$ on October 4 and the lowest value is $293.1 \mathrm{kWh}$ on October 3. The average value of electricity consumption outside of holidays when the production zone is around $296.9 \mathrm{kWh}$ This confirms the value of energy consumption from the average cycle calculation in Table 1 is acceptable.

For the amount of electricity in the storage zone, there is a difference in the average energy consumption between September 27-30 and the later date. The calculation result of the average energy consumption of $\mathrm{kWh}$ on September $27-30^{\text {th }}$ is $415,555 \mathrm{kWh}$ while for the following day the average is $335,025 \mathrm{kWh}$, excluding holidays. In storage zones, the most influential variable is the number of products stored. Due to the lack of detail of the amount and time of product entry and exit from CS, the analysis is based on the assumption of maximum and minimum data stored products (between $150 \sim 170$ tons). The difference in power measurements at that date is assumed to be the difference in the number of products stored in CS, namely that on Sept, $27-30^{\text {th }}$, the amount reaches a maximum of 170 tons, then on the next date the product is released so that the amount is reduced to 150 tons. While the average value of 1 week for storage zones is $375.29 \mathrm{kWh}$.

Based on these results, the average energy usage per day (24 hours) for CS can be calculated: the average amount of energy production zone + average amount of energy storage zone $=296.9+375.29 \mathrm{kWh}=672.19 \mathrm{kWh}$ during the day of operation, and for holidays measured $260.9+269.1=530 \mathrm{kWh}$. If the assumption is taken that the average number of stored products is 160 tons, then the specific energy consumption is $672.19 \mathrm{kWh}$ / 160 tons $=4.2 \mathrm{kWh} /$ ton.

\subsection{Air Blast Freezer (ABF) Energy Consumption}

The analysis carried out is a function of the number of production and cooling cycles. With the limitation of detailed production data per day, the analysis was carried out at Sept, 27, $28,30^{\text {th }}$ and Oct, $3^{\text {rd }}$. On these dates, the amount of production data and information about ABF was completely obtained.

Just like CS, ABF also consists of compressors, air cool blowers and evaporator blowers and valve expansion. The difference is that $\mathrm{ABF}$ works to catch up to the target temperature as soon as possible. However, the compressor cannot go directly to the target temperature, but rather has to be done in several cycles of the compressor working. For example, an analysis of ABF's work was conducted on 27-30 September with a product in the form of $5024 \mathrm{~kg}$ of tuna and a target air temperature of $-25^{\circ} \mathrm{C}$ or around $-30^{\circ} \mathrm{C}$ on the product. The $\mathrm{ABF}$ used is $\mathrm{ABF} \# 2$, work cycle start at 14:30 and ends at 10:30 the next day or about 20 hours. The compressor works to suppress the coolant every six hours with a working time of about 15 minutes. The maximum electrical power reaches around $33 \mathrm{~kW}$ so that the average energy while the compressor is working is $25,100 \mathrm{Wh}$. In one cycle there are 5 times the compressor start-up. After that the compressor stops working, but the blower stays on and the $\mathrm{ABF}$ works in steady run condition. Figure 4 shows the ABF operating pattern.

Table 4 shows the ABF 2 work cycle calculation. Under steady run conditions, when only the blower is on, the average energy needed is $21,550 \mathrm{Wh}$. Thus, in one ABF work cycle on that date requires around $436.6 \mathrm{kWh}$ of energy. The results of this calculation will be confirmed by the results of the energy measurements presented in Table 5. The energy measurement cycle in Table 5 is adjusted to the graph reading in Figure 4. 


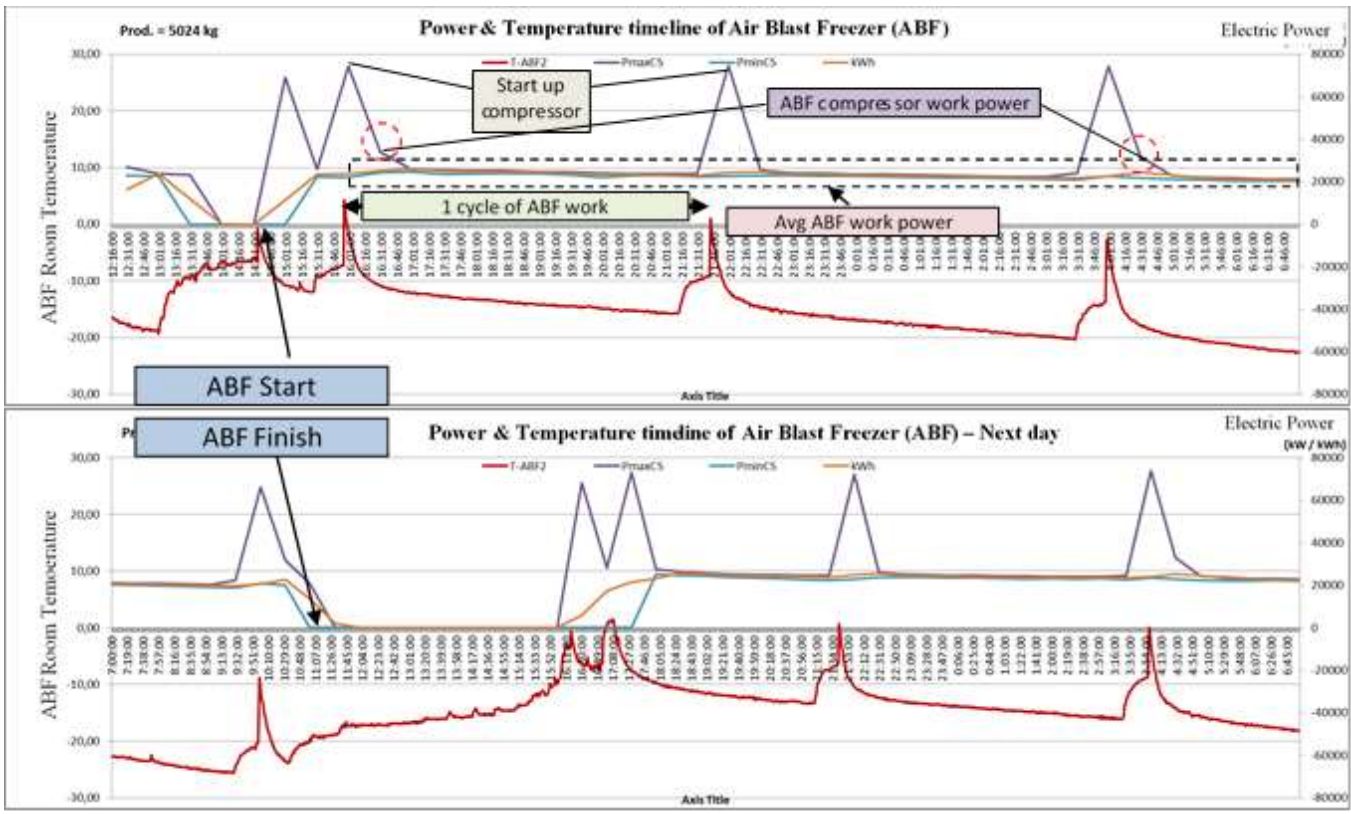

Fig. 4. Operating pattern of air blast freezer (ABF) at PT. JLM

Table 4. Work cycle of the ABF \#2 engine (14:30 - 10:30) on Sept, $27 \sim 28^{\text {th }}$

\begin{tabular}{|c|c|c|c|}
\hline Process & Duration & $\begin{array}{c}\text { Power }(k W) \\
(\max -\min )\end{array}$ & $\begin{array}{l}\text { Avg. Energy } \\
\text { (Wh) }\end{array}$ \\
\hline Start up compressor & $<1 \mathrm{sec}$ & $74800 \sim 69200$ & \\
\hline $\begin{array}{l}\text { Running compressor } \\
\text { (compressor\& all blower on) }\end{array}$ & $5 \times 20 \mathrm{~min}$ & $26100 \sim 24300$ & 25100 \\
\hline Steady run (only blower on) & $\begin{array}{l}\text { 14:30 10:30 (minus } \\
\text { compressor run time) }\end{array}$ & $23400 \sim 19700$ & 21550 \\
\hline \multicolumn{2}{|c|}{$\begin{array}{l}\text { Total energi }(\mathrm{kWh}) \text { of } \mathrm{ABF} \text { at production zone ( } 1 \text { cycle of } \\
\mathrm{ABF} \text { working time) }\end{array}$} & \multicolumn{2}{|c|}{$\begin{array}{l}=(25100 \times 1,6)+(21550 \times 18,4) \\
=40160+396520=436680 \mathrm{Wh} \\
=436.6 \mathrm{kWh}^{*}\end{array}$} \\
\hline
\end{tabular}

*) The average $\mathrm{kWh}$ method here is only a rough depiction of the $\mathrm{kWh}$ calculation that occurred, while the real $\mathrm{kWh}$ that occurred will be presented below at Table 5 , as confirmation of this calculation.

Table 5. Electrical energy measurement results in panel \#2 ABF.

\begin{tabular}{|c|c|c|c|c|c|c|c|c|}
\hline \multirow[b]{2}{*}{ Date } & \multicolumn{5}{|c|}{ Cycle of ABF \#2 } & \multirow{2}{*}{$\begin{array}{c}\text { Prod. } \\
\text { Qty } \\
\text { (kg) }\end{array}$} & \multirow{2}{*}{$\begin{array}{c}\text { Energy } \\
\text { Intensity } \\
\text { (Wh/kg) }\end{array}$} & \multirow[b]{2}{*}{ Notes } \\
\hline & Start & (Wh) & Stop & (Wh) & $\begin{array}{l}\text { Energi } \\
\text { (Wh) }\end{array}$ & & & \\
\hline Sept, 27 28 ${ }^{\text {th }}$ & $14: 30$ & 28400 & $10: 30$ & 484700 & 456300 & 5024 & 90.82 & \\
\hline Sept, 28 29 ${ }^{\text {th }}$ & 16:00 & 486800 & 16:00 & 1013600 & 526800 & 5325 & 98.93 & \\
\hline $\begin{array}{l}\text { Sept, } 30^{\text {th }} \sim \\
\text { Oct, } 1^{\text {st }}\end{array}$ & $11: 30$ & 1020500 & 14:00 & 1622300 & 601800 & 5405 & 111.34 & \\
\hline Oct, $1 \sim 2^{\text {nd }}$ & & & & & 0 & 0 & 0.00 & Holiday \\
\hline Oct, $2 \sim 3^{\text {rd }}$ & & & & & 0 & 5124 & 0.00 & use $\mathrm{ABF} \# 1$ \\
\hline Oct, 3 4 $4^{\text {th }}$ & 13:00 & 1663700 & $1: 00$ & 1928600 & 264900 & 1852 & 143.03 & \\
\hline $4 \sim 5 \mathrm{Okt}$ & $16: 30$ & 1959200 & $0: 30$ & 2121100 & 161900 & 331 & 489.12 & \\
\hline
\end{tabular}


It can be seen from Table 5 that ABF's work is very much determined by the amount of products cooled, the more products that are cooled, the energy consumption will increase. However, the lowest value of energy intensity is achieved when production is around 5,000 $\mathrm{kg}$ as shown in Figure 5. For production below and above 5,000 kg, the energy needed is greater. When the production is around $5,000 \mathrm{~kg}$, the specific energy consumption reaches around $91 \mathrm{Wh} / \mathrm{kg}$, while for the production of around 5,300 - 5,400 kg, the specific energy consumption increases to $105.1 \mathrm{Wh} / \mathrm{kg}$. Likewise if the production is only around 2,000 kg, the specific energy consumption reaches $145 \mathrm{Wh} / \mathrm{kg}$. For $1,000 \mathrm{~kg}$ of production, it will be increasingly inefficient with specific energy consumption reaching $250 \mathrm{Wh} / \mathrm{kg}$.

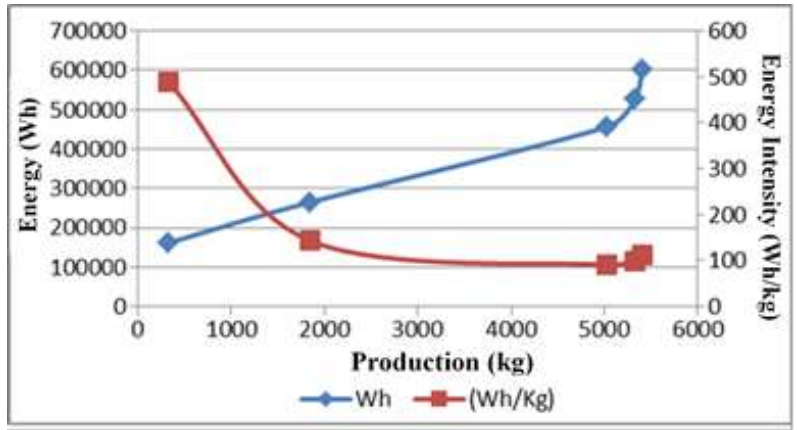

Fig. 5. Graph of energy consumption vs production

Based on the results of the discussion above, the steps that need to be taken by the plant manager to increase electrical energy savings include:

- The use of variable frequency drive [17-19] to regulate the electric motor driving the compressor on CS and ABF when the load is not full.

- Using a soft starter to reduce peak flow at start-up [17, 19], can be used to reduce the electric power subscriptions from PLN.

- The pattern of cold storage operations can be optimized by determining more effective product transfer procedures to reduce CS doors opened and closed repeatedly.

- The use of ABF is better operated with a production of more than $2,000 \mathrm{~kg}$, if you have to work with a smaller number of products, then consumers need to be subjected to higher price adjustments.

- Need more detailed measurements at regular intervals to determine the efficiency of existing $\mathrm{CS}$ and $\mathrm{ABF}$ machines to find out the performance degradation of the equipment after a long time of operation. This needs to be done because there is no standard specification of the equipment.

\section{Conclusion}

Based on cold storage work is determined by the number of products stored. Cold storage work becomes greater when there are open and close doors when moving products (hours of production). Specific energy consumption for cold storage reaches around $4.2 \mathrm{kWh} /$ ton or $4.2 \mathrm{Wh} / \mathrm{kg}$.

ABF's work is determined by the number of products frozen. The more production, the higher the energy needed. However, the optimal value of ABF work will occur if it produces in the range of $5,000 \mathrm{~kg}$, with the energy needed per production weight is $91 \mathrm{Wh} / \mathrm{kg}$. If production is higher than $5,000 \mathrm{~kg}$, the energy requirements per weight will be higher. Likewise, if $\mathrm{ABF}$ has to cool the product below 2,000 $\mathrm{kg}$ because the value of its specific energy consumption will increase to reach $145 \mathrm{Wh} / \mathrm{kg}$. 
Acknowledgement. This research was funded by DIPA Ministry of Energy and Mineral Resources in. Thank you to PT. Jala Lautan Mulia Sidoarjo which has given permission for this research.

\section{References}

1. FAO, The State of World Fisheries and Aquaculture 2016 (2016).

2. D. Wijayanto, Aquat. Procedia 7, 28 (2016).

3. H. Darvishi, M. Azadbakht, A. Rezaeiasl, and A. Farhang, J. Saudi Soc. Agric. Sci. 12, 121 (2013).

4. R. C. Nagarajarao, Aquat. Procedia 7, 201 (2016).

5. H. Wu, S. A. Tassou, T. G. Karayiannis, and H. Jouhara, Appl. Therm. Eng. 53, 332 (2013).

6. H. Ronde, A. Ranne, and E. Pursiheimo, Proc. Int. Conf. Energy Sustain. Dev. Issues Strateg. ESD 2010 (2010).

7. Y. A. Çengel and A. J. Ghajar, in Heat Mass Transf. Fundam. Appl. Refrig. Freez. FOODS, 5th ed. (McGraw-Hill Education, 2015), pp. 1-59.

8. J. Evans, A. Foster, J. M. Huet, L. Reinholdt, K. Fikiin, C. Zilio, M. Houska, A. Landfeld, C. Bond, M. Scheurs, and T. Van Sambeeck, Refrig. Sci. Technol. 2815 (2015).

9. Postharvest Management of Vegetables, Cool Room. URL: https://www.postharvest.net.au/postharvest-fundamentals/cooling-and-storage/coolrooms//. Last update: 17 Februari 2019, (accessed at: 10 February 2020 )

10. A. Murtono, P. N. I. Kalangi, and F. E. Kaparang, J. Ilmu Dan Teknol. Perikan. Tangkap 2, 89 (2016).

11. R. Meléndez-Pérez, M. E. Rosas-Mendoza, C. M.- Márquez, R. R. Velázquez-Castillo, and J. L. Arjona-Román, Procedia Food Sci. 1, 363 (2011).

12. Indonesian Agency of National Standardization (BSN), SNI 6196:2011, BSN (2011).

13. Government Regulation of Republic Indonesia, No. 70 Year 2009 about Energy Conservation.

14. B. Ates, K. N. Widell, T. S. Nordtvedt, and A. L. Cojocaru, Refrig. Sci. Technol. 256 (2017).

15. J. F. Muir, Fuel and Energy Use in the Fisheries Sector - Approaches, Inventories and Strategic Implications (2015).

16. Indonesian Agency of National Standardization (BSN), SNI 4110:2014, BSN (2014).

17. Sofyar, E. Firmansyah, and Suharyanto, in CITISEE 2016 (CITISEE 2016, Yogyakarta, 2016), pp. 23-24.

18. T. Aditya, Int. J. Sci. Res. 2,2319 (2013).

19. K. Gandhi, KL. Mokariya, D. Karvat, and M. Raval, IJERT 3, 2128 (2014). 